\title{
Retinoic Acid Receptor Gamma
}

National Cancer Institute

\section{Source}

National Cancer Institute. Retinoic Acid Receptor Gamma. NCI Thesaurus. Code C38578.

Retinoic acid receptor gamma (454 aa, $\sim 50 \mathrm{kDa}$ ) is encoded by the human RARG gene.

This protein is involved in transcriptional regulation mediated by retinoic acid binding. 